\title{
18. \\ OD KORZETA DO HLAČA: \\ MODA U ZAGREBU \\ U RAZDOBLJU MEĐURAĆA
}

\section{Andrea Buzov}

UDK: 391(497.5 Zagreb)“1918/1941“

Prethodno priopćenje

Sažetak: Razdoblje između dvaju svjetskih ratova donosi niz promjena u Zagrebu. Bilo je to, između ostalog, vrijeme modernog preobražaja grada koji je u Kraljevini Srba, Hrvata i Slovenaca bio jedan od glavnih urbanih centara zbivanja. Promjene su se očitavale u raznim domenama, naročito u društvenoj raslojenosti, ali i na kulturnim i umjetničkim poljima. Sve je to utjecalo i na položaj žene, one srednjeg i višeg društvenog sloja, a samim time i na njezin odjevni kôd. Odjevni kôd analizirat će se na temelju nekoliko ženskih časopisa koji su izlazili u razdoblju od 1918. do 1941. Oni su u to vrijeme predstavljali važnu komponentu u razvoju i promjeni ženske mode. Kako se ona transformirala, tako je jačala društvena kritika te nerijetko dolazi do otpora i sukobljavanja s tradicijom. Među glavnim zagovornicama promjene i transformacije žene i ženske odjeće u tom razdoblju treba izdvojiti Mariju Jurić Zagorku, kao jednu od pionirki prihvaćanja i zagovaranja promjena.

Ključne riječi: Zagreb, moda, međuraće, žena, odjeća

\section{UvoD}

7 agreb nakon dugogodišnjeg bivanja u sastavu Habsburške Monarhije i njezina raspada doživljava transformaciju od perifernoga dijela Monarhije u jedan od centralnih dije$\triangle$ lova nove tvorevine, isprva Države Srba, Hrvata i Slovenaca, kasnije Kraljevine SHS/ Jugoslavije. Taj period obuhvaćen je nizom promjena. Vrijeme nakon Prvog svjetskog rata prije svega znači povećanje gradskog stanovništva, što se naročito odražava na Zagreb. U to doba i moda te odijevanje dobivaju važniju ulogu u životu ljudi. U međuratnom razdoblju procesi koji su započeti u drugoj polovini 19. stoljeća i oko 1900. godine postaju vidljiviji i izraženiji u svakodnevnom životu. Moda postaje važniji element, prisutnija i usklađenija $s$ vizijama „nove“ žene u odnosu na različite ekonomske, društvene i kulturne aspekte koji 
su obilježili međuraće. Može se reći da se u tom periodu ocrtavaju i naznake globalizacije u smislu sve proširenije kulture slavnih i poznatih. ${ }^{1}$ Velik utjecaj na modu tako počinju vršiti kazališni i naročito filmski glumci, glazbenici i druge slavne osobe, osobito kinematografijom (1906. godine Zagreb dobiva svoje prvo kino) i popratnim filmskim revijama ili listovima. Aktualni trendovi popularnih glumaca dobivaju na značenju. Nadalje, slavne i popularne osobe tog vremena postaju „sveprisutnije“ u svakodnevnici organiziranjem niza manifestacija, koje su na temelju tiskovina ili uživo pratile šire publike, kao što je prvi izbor za miss Jugoslavije u hotelu „Esplanade“, u kojem je Štefica Vidačić odnijela titulu najljepše ${ }^{2}$ ili, primjerice, nastup Josephine Baker u toplessu u istom hotelu u Zagrebu. Sve to ojačava praćenje nastupajućih trendova i širenja modnih noviteta.

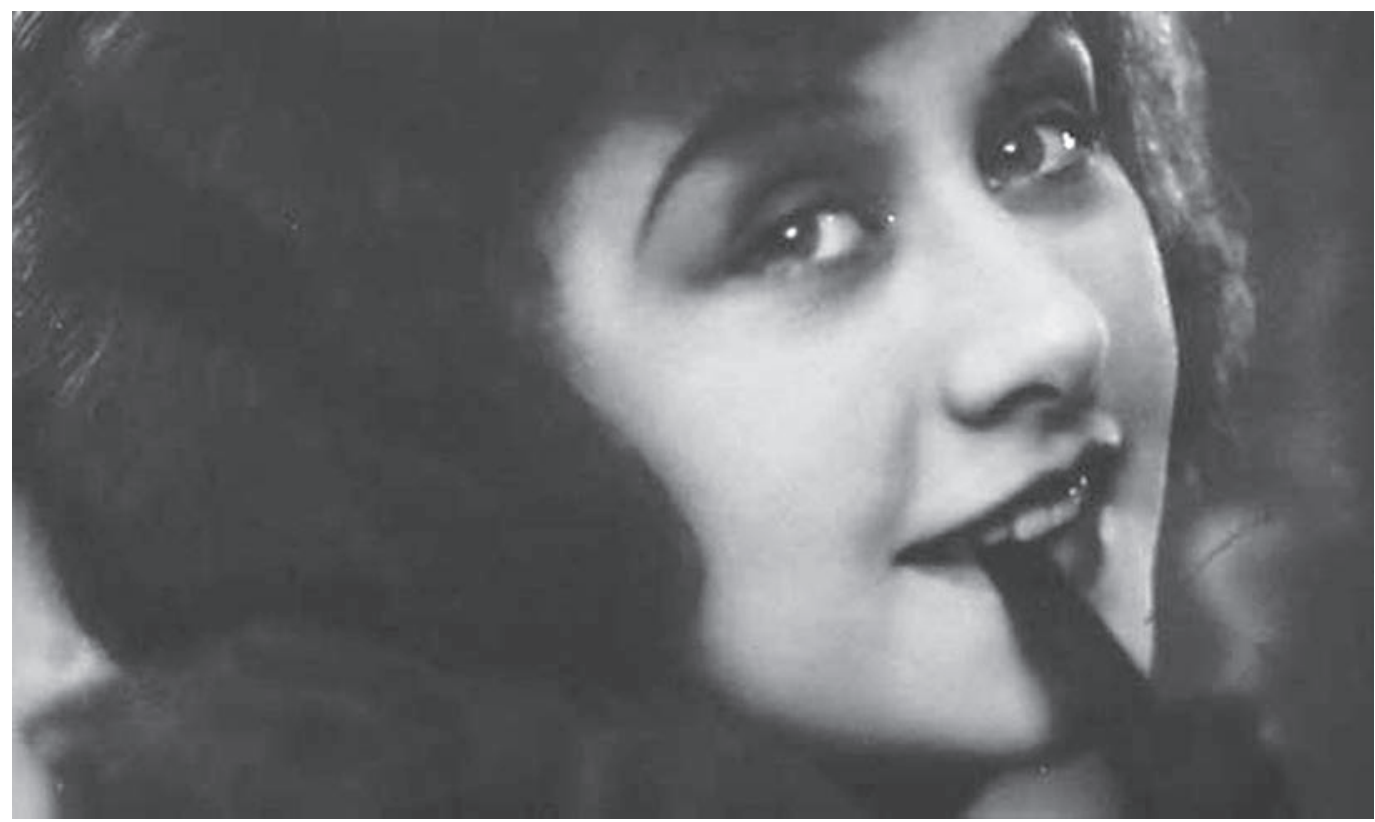

Sl. 1. Štefica Vidačić, Miss Kraljevine SHS 1926. i Miss Europe 1927. godine (Izvor: https://100posto.hr/scena/zagrepcanka-postala-prva-miss-europe)

U fokusu je ovog rada žena, i to ona srednjeg i višeg društvenog sloja koja je u mogućnosti pratiti te društvene aktualnosti i može si financijski priuštiti držanje koraka s modnim novìnama.

Nadalje, odabrana je ženska figura jer je Prvi svjetski rat za žene „kolektivno iskustvo“ koje ih je - što nije bio slučaj u ranijim razdobljima u prošlosti - više nego ikada prije integriralo u društvenom smislu, pomičući iz potrebe brojne barijere, norme i granice, stoga nove okolnosti od žene zahtijevaju promijenjenu i istaknutiju ulogu u društvu.

1 Koncept „slavnih“, odnosno tzv. celebrity status neki stručnjaci, poput francuskog povjesničara Antoinea Liltija, promatraju kao mehanizam koji se razvija od prosvjetiteljstva te upravo oko kraja 18. i početka 19. stoljeća postaje uočljiv na objema stranama Atlantika. V. Antoine LiLTI, The Invention of Celebrity, Cambridge 2017. 
$\mathrm{Na}$ temelju niže navedenih modnih časopisa toga doba promotrit ćemo pobliže aspekte kao što su stav hrvatskog tiska prema ženi i modi te očitovanje društvene zajednice i vanjsku percepciju na modne promjene. Temelje za to postavila je Katarina Nina Simončič u djelu Kultura odijevanja u Zagrebu na prijelazu iz 19. u 20. stoljeće, kojim je otvorila prostor za temeljitije proučavanje razvoja i transformacije mode, kao i Ida Ograjšek Gorenjak u knjizi Opasne iluzije. Rodni stereotepi u meduratnoj Jugoslaviji, u kojoj se na studiozan način pristupa ženskom položaju kroz prizmu stereotipa.

\section{Pojam mode}

Moda (od lat. modus - način, pravilo, ritam, vrijeme) termin je koji označava popularne stilove u raznim sferama ljudskih aktivnosti i razmišljanja. Označava nešto promjenjivo, nestabilno i prolazno. Modne promjene u raznim područjima dovode i do promjene kulture u cijelosti. ${ }^{3}$

Od antike pa do 14. stoljeća dogodili su se maleni pomaci te tek otada nadalje dolazi do diferencijacije ženskog i muškog odijevanja. ${ }^{4}$ Nakon toga se određene društvene skupine modom i odjećom koriste za distanciranje od ostatka zajednice. ${ }^{5}$

Ingrid Loschek mišljenja je da pojam mode ne podliježe jedinstvenoj definiciji te se treba izučavati kao osobni izričaj vlastitog načina života i mišljenja jedne skupine ljudi u istom periodu. ${ }^{6}$ Moda je pitanje interdisciplinarnosti i stoga se nikako ne može uzeti kao površni konstrukt ili proizvod, nego kao vrlo složen fenomen s mnogim pojedinačnim aspektima. Između ostaloga, važno je kritičko i društveno propitkivanje tog fenomena, kao i pitanje identitetskog označitelja kojeg ono nosi u sebi, ali i poruke koja se njome želi odaslati.

Ovdje treba spomenuti i Georga Simmela, jednog od prvih sociologa koji je obradio temu mode i njezine teorije. Pretpostavlja da moda služi za imitaciju i razgraničenje. Ovaj dualizam objašnjava prije svega na temelju društvenih slojeva. Prema Simmelu, modu diktira gornji društveni sloj. Čim je donji sloj prihvati i počinje oponašati, gornji društveni sloj mijenja je za nešto drugo jer gubi funkciju diferencijacije. ${ }^{8}$ Iz toga proizlazi da je gornja društvena skupina ubrzala modnu promjenu.

Drugi je važan aspekt razlikovanje pojma mode i odjeće. Na prvi se pogled ova dva pojma često uzimaju kao sinonimi. No, iako posjeduju neke sličnosti, razlikuju se po svojim karakteristikama i izrazima. Moda je povezana s estetskim izrazom, rjeđe s funkcijom za-

2 Boris Vukonić, Tempus fugit. Povijest turizma Zagreba, Zagreb 1994., 125; Ida Ograjšek Gornjak, „Hollywood Comes to Central Europe: The Fanamet Beauty Contest in Central Europe and Southeastern Europe“, u: The Entangled Histories of Vienna, Zagreb and Budapest (18 ${ }^{\text {th }}-20^{\text {th }}$ Century) (ur. Iskra Iveljić), Zagreb 2015., $215-233$.

Ingrid LoscheK, Reclams Mode- und Kostümlexikon, Stuttgart 1994., 358-359.

4 Mirna Cvitan-Černelić, „Odijevanje u zrcalu povijesti“, u: Moda. Povijest, sociologija i teorija mode (ur. Mirna Cvitan-Černelić, Djurdja Bartlett i Ante Tonči Vladislavić), Zagreb 2002., 12.

5 Ivana BiočınA, Modus vivendi. Ogled o političkom, ekonomskom i društvenom u modi, Zagreb $2014 ., 39$.

6 I. Loscheк, Mode, Verführung und Notwendigkeit, München 1991., 160.

7 Isto.

8 Georg Simmel, Kontrapunkti kulture, Zagreb 2001., 40. 
štite i prekrivanjem tijela, dok se odjeća smatra objektom koji pruža zaštitu od različitih vremenskih uvjeta.?

Odjeći izgled daje dizajn, a moda dobiva svoje značenje tek prihvaćanjem od strane društva. Odjevni predmet postaje modnim tek u okviru prezentacije na modnim revijama i oglašavanjem.

Modni odjevni predmeti daju odjeći društvenu svrhu te ona zahvaljujući modi dobiva svoj ekonomski, kulturni i simbolički pečat. ${ }^{10}$

Kao što je već istaknuto, funkcija je odjeće da zaštiti tijelo od različitih klimatskih uvjeta ili da naglasi određene dijelove tijela. U povijesti je često bio slučaj da je utjecajem različitih modnih trendova odjeći bila proširena njezina primarna funkcija, što na kraju snažno pridonosi oblikovanju ženske siluete. Tako je krajem 19. stoljeća u Europi (Engleska, Skandinavija, Njemačka) došlo do reformskog pokreta koji se okrenuo protiv tada ekstremnog modeliranja ženskog tijela nošenjem korzeta. ${ }^{11}$ Protest je bio potaknut činjenicom da je nošenje steznika štetno za žensko tijelo pa buržoazija propagira tzv. reformsku haljinu, koja oslobađa tijelo i daje ženskom liku potpuno novi izgled. ${ }^{12}$

\section{TISAK O MODI}

Pod pojmom ženski modni tisak podrazumijevaju se listovi koji prate određena područja života žene, kao što su obiteljski život, zabava, zastupanje interesa žena i njihovih prava. Nerijetko nude ženama i poučnu notu te edukacijski karakter. ${ }^{13}$

U ovom radu koristilo se nekoliko časopisa:

Ženski list za modu, zabavu i kućanstvo mjesečnik je pod uredništvom Marije Jurić Zagorke i izlazi od travnja 1925. do travnja 1938. godine. Izdaje se u Zagrebu te se mogao kupiti u knjižarama ili pretplatom. Časopis donosi krojne arke, priloge iz kulture, reklame kućanskih proizvoda, ali i modne savjete te smjernice za ostvarivanje pune ljepote žene. Čitateljice su imale i priliku same tematski usmjeravati časopis ispunjavajući Anketu Ženskog lista. Tako časopis s vremenom postaje sadržajno sve bogatiji i zanimljiviji te donosi savjete iz raznih područja, kao što je briga za zdravlje žene, obrađuje obiteljsku i bračnu tematiku, uljepšavanje i odijevanje..$^{14}$

Hrvatski ženski list izlazi od travnja 1939. do prosinca 1944. godine. Izdaje se u Zagrebu, glavna urednica bila je Sida Košutić, a od šestog broja iz 1943. godine tu funkciju obnaša

\footnotetext{
Milan Galović, Moda. Zastiranje i otkrivanje, Zagreb 2001., 11-14.

10 I. Loscheк, When Clothes Become Fashion: Design and Innovation Systems, Oxford - New York 2009., 135.

11 Jutta Zander-Seidel, Kleiderwechsel. Frauen-, Männer-und Kinderkleidung des 18. bis 20. Jahrhunderts, Nürnberg 2002., 24 .

12 Karen Ellwanger, „Reformkleidung, Geschlecht und Nationalität“, u: Kleider machen Politik. Zur Repräsentation von Nationalstaat und Politik durch Kleidung in Europa vom 18. bis zum 20. Jahrhundert, Oldenburg 2002., 89.

13 Marina Čızmić-Horvat, „Ženski listovi u hrvatskom novinstvu“, Riječ, 11/2005., br. 2, 101-102.

14 Andreja ZuBAC, „Kultura javne riječi ženskih časopisa od 1840. do 1970. godine“, Knjižničarstvo: glasnik Društva knjižničara Slavonije i Baranje, 20/2016., br. 2, 79-80.
} 
Mara Schwel. Vizualno podsjeća na Ženski list te tematski povezuje tradiciju s aktualnostima, kao što su kultura, ples, moda i kućanstvo. ${ }^{15}$

Naša žena - tjednik za ženski svijet izlazi od 1935. do 1938., s glavnim ciljem pružanja podrške ženi u svakodnevici te cjenovnom dostupnošću.

Već se dulje vremena u našem javnom životu osjeća potreba jednog jeftinog ženskog lista. Teške ekonomske prilike prisilile su gotovo svaku porodicu da se ograniči i stegne na ono najnužnije. Mi smo daleko od toga, da se povedemo za principima pretjeranih feministkinja, ali smo odlučno za to, da se u našem društvu ženi i važnosti njenoga djelovanja dade dolično mjesto. ${ }^{16}$

Svijet se izdaje od 1926. do 1938.; bile su to prve ilustrirane hrvatske novine. Na uredničkom čelu bio je Otto Antonini. Sadržajno je donosio priloge iz društvenog života, zabave, mode, glazbe i umjetnosti, kao i sporta te političkog života. ${ }^{17}$

Kao što je vidljivo, časopisi za ženu uključuju se u širi društveni spektar, što i nije neobično s obzirom na vladajuće okolnosti međuraća koje zahtijevaju prošireniju ulogu žene. Ona sada nije samo kućanica i majka, nego preuzima aktivniju ulogu u zajednici i teži zapošljavanju. ${ }^{18}$

Modni časopisi ne samo da izvještavaju svoje čitateljice o tome što se trenutno nosi npr. u Beču nego i iznose svoje stavove i primjedbe na vladajuće modne stilove. Prate kako moda prožima društvo i preobražava stari društtveni poredak te se koriste svojim utjecajem kako bi potaknuli žene da više promišljaju o svom stilu, a ne da samo oponašaju svaki novitet bez proturječnosti. Tako se mijenjaju društvene konvencije te modelira ljepota žene. S obzirom na to da su žene bile uskraćene u političkim, ekonomskim i drugim pravima, one odjećom nastoje izraziti svoj stav prema društvenim zbivanjima.

- Vidiš, ovo je lijepo, - veli on - jednostavno i otmjeno.

- Ne svidja mi se - pristajalo bi više kakvoj staroj dami.

- Na mladom tijelu kakvo je tvoje sve je mladjahno i lijepo. A ne bi li ovo?

- Ali, pusti, molim te - preporučaš mi same staračke fazone. Ne ću da izaberem. Ne ću nove haljine.

- Tim bolje - barem ja ne trebam platiti.

- Tako! Dakle za to si mi odabrao takve fazone samo da ne kupim haljinu? Ja ću je ipak kupiti. I opet stade listati po žurnalu:

- Tako. Ovo ću uzeti - baš ovo.

- Ali, draga Milkice, ovo je ipak premalo otmjeno - izgledat ćeš kao kabaretna plesačica.

- Tako izgledaju danas sve žene, valjda ne ću ja da nosim „šlep“ kao stari žurnal. Trebam haljinu za nedjeljni soare, a fazona će biti ova.

- Kakvu ćeš uzeti boju? - upita on ne prigovarajući dalje.

- Crvenu - onako svijetlo-crvenu.

- Ali, Milkice - crvena soare-toaleta! To ipak ne možeš.

- Zašto ne?

- Jer će sve dame našega kluba odjenuti otmjene haljine finih boja. ${ }^{19}$

15 Isto, 82.

16 „Predgovor“, Naša žena, 1/1935., br. 1, 2.

17 Josip Horvat, Povijest novinstva Hrvatske 1771-1939., Zagreb 1962., 391.

18 A. ZuBAC, „Kultura javne riječi ženskih časopisa od 1840. do 1970. godine“, 78.

19 „Crvena haljina“, Ženski list, 6/1925., br. 3, 16. 
Gore citirani odlomak vrlo dobro ilustrira odnos u bračnoj zajednici i notu podređenosti žene čak pri izboru odjevnih predmeta, kao i njezinu želju za pravom na vlastiti izbor. Međutim, iz toga je vidljivo da žena ustvari ne bira odjeću vođena osobnim preferencijama, već njezin izbor nastaje pod utjecajem modnog tiska, što govori o tome da ona biva usmjeravana i homogenizirana, $s$ jedne strane okolinom i muževim stavom, a s druge onim što modni tisak izlaže kao poželjno i pomodno.

Nadalje, uočava se da modu i ono što se predstavlja kao prihvatljivo i nosivo nikako nije usvajala cijela ženska publika. Ovakav način pisanja o modnim pojavama osvješćuje činjenicu da primarna namjera stvaranja modnih noviteta nije bila samo uljepšavanje žene već $\mathrm{i}$ buđenje prvih konzumerističkih nagona, a samim time i povećanje potrošnje.

Osobito pakao bilo ih je u prošlim godinama gdje je moda kolebala, stvarala svakog časa tendencije da od žene učini neko polumuško biće, da suknje podreže do preko koljena - što je naravno bilo sasvim suvišno - i moramo priznati nikako lijepo. Takovim su se zabludama odupirale i same žene, dok se konačno nije moda odlučila da bude decentnija. Ali ta moda nije nikako mogla da upliva na dušu žene i da u njoj olabavi osjećaj morala. Bilo je nešto novo, nešto neobično - nešto senzualno, što se je na čas svidjelo mnogima a mnogima opet nikako. (...) A konačno i žene ne kroje modu. Moda jest i ostat će uvijek posljedicom novih iznašašća, posljedicom trgovačkih potreba i manipulacija, izrazom prilika dnevnog života i spekulacijom industrije, a nipošto izrazom labavog morala. ${ }^{20}$

Kritički se promišlja i debatira o promjenama koje su zahvatile odjevni kôd žena. Prosuđuje se o snažnoj potrebi i nametanju okoline za praćenjem modnih novotarija, kao i osjećaja izolacije od strane društva u slučaju njegova neprihvaćanja. Do izražaja dolazi tendencija robovanja društvenim očekivanjima.

Oznaka je našeg vremena, da se negdje u velikom svijetu stvori neki „tip“, i taj se onda kopira u hiljade i stotine primjeraka. A ima žena, kojima su sve te modne novotarije dosadne i mrske, no one ih ipak primaju i primjenjuju na svoj vlastiti život od samog straha, da ne bi izgledale u očima svijeta „nemoderne“. ${ }^{21}$

Društveni status žene mijenja se te ona dobiva i zauzima sve više mjesta u javnom životu, no njezina uloga u obitelji, teret kućanskih poslova i briga o djeci ostaju isti.

Svaki taj istup žena u borbu za opstanak i njena pojava u čitavom javnom životu pokazuju, da se je ona odrekla dosadanjeg mira, nerada i bez brige - i upregnula se pod kola i da bude majkom, da vodi kuću i da se - bori za opstanak. I namještena i radna žena biva majkom, vodi svoju kuću - kao dosele - s tom razlikom, da sad nema toga pomoćnog kućnog osoblja kao nekoć. Za sve dosadanje dužnosti ona postaje još i zaradjujuća snaga. ${ }^{22}$ Osim toga današnja žena mora mužu pomoći uzdržavati kuću. (...) Kraj svega toga ona još ima da bude i ono, što je bila žena pred 50 godina: žena, ljubavnica, domaćica i majka. (...). Od današnje se žene traži da bude supruga, radnik, domaćica, majka, prijatelj, drug, savjetnik, jednom riječju - sve! ${ }^{23}$

\footnotetext{
20 „Moral i moda!“, Ženski list, 10/1931., br. 3, 0.

21 „Modne novotarije“, Naša žena, 3/1935., br. 3, 12

22 „Savremena žena“, Ženski list, 3/1929., br. 3, 0.

23 „Sve što se traži od današnje žene“, Ženski list, 2/1934., br. 2, 12-13.
} 
U člancima je vidljivo isticanje višeslojnosti uloge žene u patrijarhalnoj sredini. Ženu se potiče na aktivniju borbu za svoja prava. No, i dalje se uloga domaćice stavlja u prvi plan. Pritom reklamni i modni članci od nje traže i njegovanu vanjštinu te brigu za svoj izgled. Tu jasno do izražaja dolazi proturječnost u predodžbi uloge žene kakvu nameće društvo i njezine neminovne transformacije u patrijarhalnoj sredini.

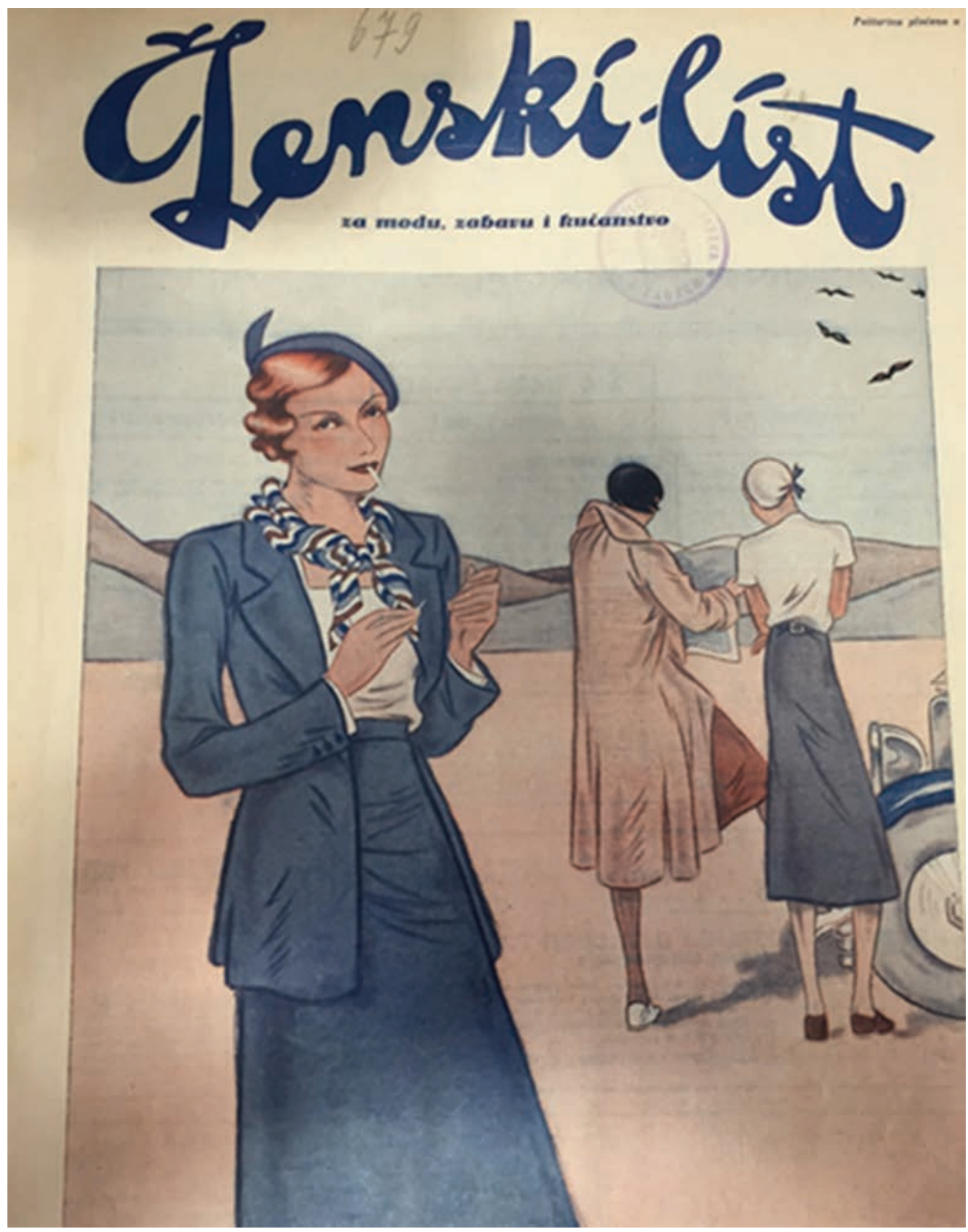

Sl. 2. Ženski list za modu, zabavu i kućanstvo, god. 8, br. 3, 1932. 


\section{4. ŽENA MEĐURAĆA I NJEZIN ODJEVNI KÔD}

Vladajuće novine međuraća odražavaju se na žensku siluetu, koja u tom razdoblju doživljava preobražaj od potpunog nastojanja da se svaka ženstvenost uguši do potpunog razotkrivanja ženskog tijela odjećom te simboličkim oslobađanjem odbacivanjem steznika.

I steznik je pao, jer je pasti morao. Uzmaknuo je kao detronizirani vladar, suveren, tiranin, otišao je kud za vazda gre se. Danas se vitka gospodja i gospodjica uopće ničim ne steže, pa ni steznikom. Nekada je tobože steznik pružao ženi vitkost, liniju, šarmantnost, milinu, izgled, stas, struk, dražest, a istom kad je pao, opaziše i žene same, da je svega toga u njih i bez steznika. ${ }^{24}$

Nakon ere korzeta, gdje je struk bio čvrsto privezan, a grudi i dekolte naglašeni, došlo je vrijeme kada je idealna ženska figura, kojoj su žene težile, bila u tipu garçon djevojke. Grudi su bile čvrsto privezane, struk je ostao tanak. Također, suknja biva skraćena, tako da ženske noge prvi put dolaze do izražaja, a samim time obuća i čarape zauzimaju novo mjesto u ženskom odjevnom kôdu.

Vrlo važan faktor naše odjeće su cipele. I najbolje odjevena žena izgledat će nekud neuredna, ako ima izgažene cipele s nakrivljenim peticama; a i najskromnije odjevena žena izgledat će skladno i uredno, ako ima lijepe cipele, dobro nalaštene i ne premalene. Svaka žena, koja mučno tracka u pretijesnim ili prekratkim cipelama nakazna je, pa bila obučena po najnovijoj pariškoj modi. I cipele s vrlo visokim potpeticama neukusne su za šetnju ulicom, a još više ako se u njima balansira u posao. Visoka potpetica spada u salon, a za ulicu vrijede trotteurs, cipele s polupetom, u koliko se - naročito po ružnom vremenu - ne da prednost niskoj, širokoj peti. ${ }^{25}$

Nadalje dolazi i do transformacije ženske frizure u takozvanu bubikopf frizuru. Sve to dokaz je pokretljivosti, brzine i funkcionalnosti novog načina života koji istodobno dodjeljuje ženi glavnu ulogu potrošačice i konzumentice mode nove ere.

Znači li to da je odzvonilo bubikopfu, koji je pri svojoj prvoj pojavi uzvitlao toliku buru protesta, izazvao tako živahne diskusije, kao možda dosad nijedna modna novotarija? Hoće li se opet ženska glavica pokloniti pred jednim od glavnih kanona ženske ljepote, koji su formulirali pjesnici i estetičari prošlih vremena, a koji u dugoj, što dužoj, i bujnoj kosi vidi ljepši ures i jednu od najzamamnijih i najplemenitijih karakteristika ženske vanjštine? Hoće li bubikopf nestati tako naglo, kao što se naglo i pojavio, da ustupi mjesto dugoj kosi? Za uvijek?26

Radi se i na podizanju razine svijesti da odjeća sama po sebi nije dovoljna za lijep vanjski izgled, već je potrebno njegovati i svoju osobnost. Mediji, u našem slučaju modni časopisi, predstavljaju niz novìna koje dopunjuju i otkrivaju žensku ljepotu te joj omogućavaju uljepšavanje i pritom reflektiraju ljepotu žene. ${ }^{27}$ Također, čitajući časopise, može se zaključiti

\footnotetext{
24 „Lagana je žena ljeti...", Svijet, 2/1940., br. 1, 51.

25 „Moda i mi“, Hrvatski ženski list, 2/1940., br. 23, 18.

26 „Bubikopf ili duga kosa“, Ženski list, 11/1927., br. 7, 31.

27 Aleksandar Todorović, Sociologija mode, Niš 1980., 36.
} 


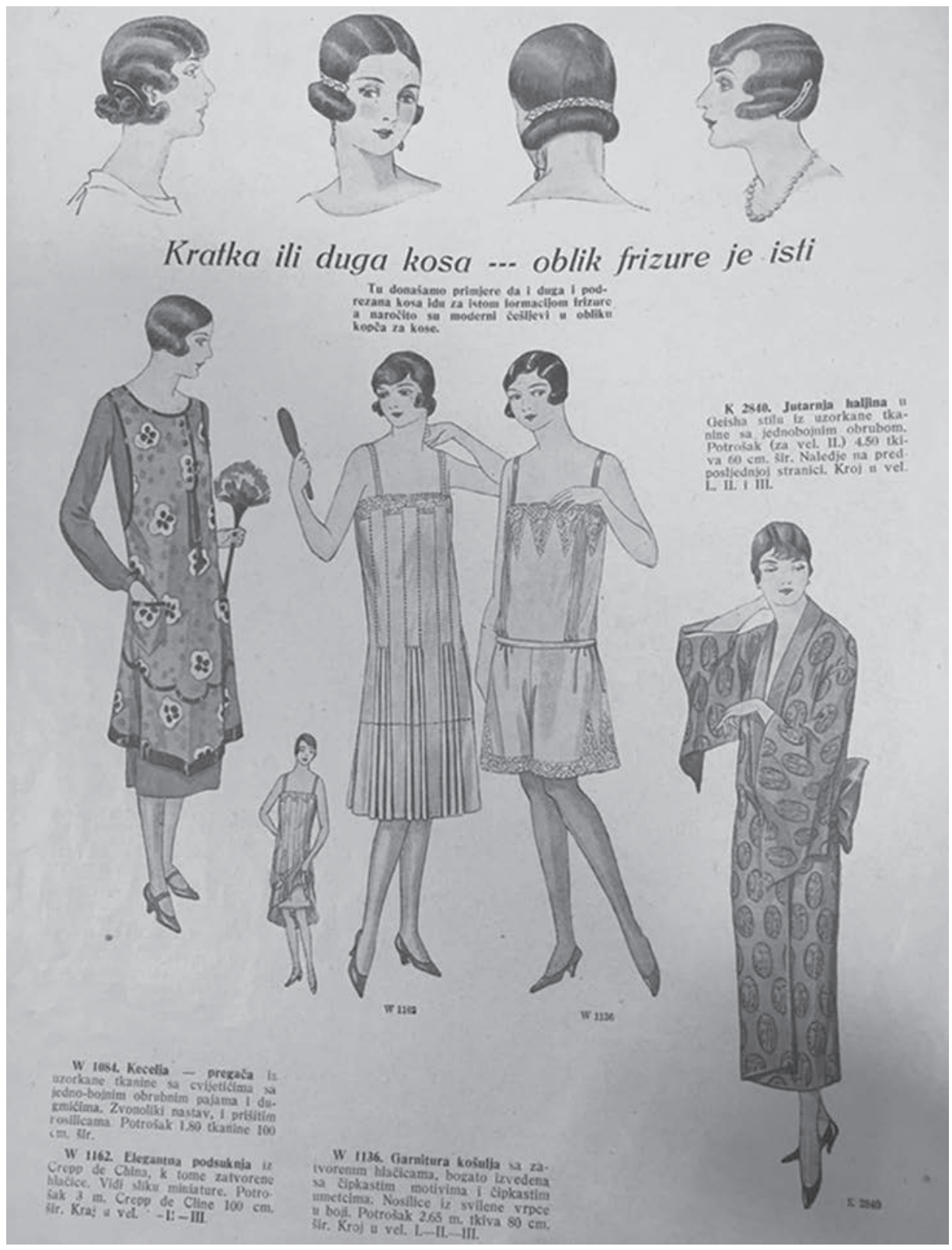

Sl. 3. Ženski list za modu, zabavu i kućanstvo, god. 1, br. 6, 1925., 25.

da su žene doista sve više prihvaćale modne trendove koji su se brzo izmjenjivali, a često sa sobom nosili novitete koji su mogli djelovati radikalno u usporedbi s prethodnim razdobljima. Stoga se u časopisima često javljaju i savjeti kako pristupiti ljepoti i što ljepota zapravo znači. Ti savjeti bili su upozorenja da se ne ovisi samo o uljepšavanju, odnosno šminkanju ili o posljednjoj modi u odijevanju. Vraćalo se na postulate njege i higijene kao pravog izvora ljepote (a onda i zdravlja) te posebice umjerenosti u ostalome, što bi podrazumijevalo posljednje modne trendove i u, dakle, uljepšavanju i odjeći. 
Svaka žena mora nastojati, da u prvom redu bude dama u pravom smislu riječi. Biti dama ne znači mijenjati toalete svakog dana ili jašiti, imati vilu, auto i sve drugo što se općenito misli da stvara ženu damom, a što se može nabaviti novcem. Biti dama, otmjena žena, može svaka, koja znade i može da se otrese ili da obuzda svoje loše osebine. Žena postaje dama kad sve ženske dobre osebine njeguje, a loše istisne iz sebe. U svakoj ćemo prilici bilo na ulici, u dućanu, u lokalu, svagdje, a osobito kod kuće prepoznati: to je dama. Zašto? Odgovor je vrlo kratak: Imade osjećaj za lijepo i plemenito! ${ }^{28}$

Od nje se očekuje poznavanje svoje vanjštine i jako dobre vještine prepoznavanja onoga što joj pristaje, a što ne. Nameće se praćenje modnih novìna i njihovo usklađivanje s njezinim karakterom. Žena nije slobodna donositi vlastite izbore u odijevanju, već joj se određen stil i način odijevanja nameću.

Žena, koja želi biti dobro odjevena, mora poznavati svoju vanjštinu. Ako znade kako izgleda onda će znati, kako se treba odjenuti i što će joj dobro pristajati. Mnoga su pitanja, koja si žena mora postaviti kad odabire haljine. Da li je športska pojava? - Nježna rasta? - Dobre i skladne pojave? - Nije li lice u suprotnosti sa pojavom? - I još bi se mnoga pitanja mogla staviti, kada se odabire garderoba. Sportskoj pojavi dobro pristaju visoko zatvorene i jednostavne, dapače naglašeno jednostavne haljine. U raskošnim ili ukrašenim haljinama izgubit će se njena ljepota. Nježna žena mora odabirati nježne tkanine; njoj ne pristaju grubi lan i tkanine. Visoko zatvorene haljine pristaju visokim ženama, koje nemaju jake grudi, a ženama niska rasta ako su nježne. Ako je put tamna i kosa crna, lijepo pristaje bluza sa malim izrezom, jer će doći do izražaja lijepi prelaz smedje boje vrata na obraze koji su kao malo pocrnjeli od sunca. ${ }^{29}$ Osim toga, žena je upozorena da izbor odjeće odražava dio njezinog karaktera i unutarnjeg stanja te je stoga odabir potrebno napraviti s poštovanjem, tako da se društvu ne šalje krivu sliku o sebi: „Haljina i ličnost trebaju da nose istu misao, ako želimo da ih dovedemo u sklad, da jedno drugome pristaje. Haljine treba da budu nositeljice naše misli, jer mi na njih prenosimo dio naše društvene ličnosti, a i dio našeg duševnog rada, kako to rad i znanje traži. ${ }^{30}$

\section{Pogled izvana}

Društveni pogled na promjene koje se zbivaju na području odjevnog kôda žene sve su samo ne blagonaklone. U skladu s tim se i prema ženama obraća autoritativnim i imperativnim tonom te se time oblikuje okvir javnog tumačenja promjena u odijevanju žene.

Isto se najbolje oslikava u uvođenju hlača kao odjevnog predmeta u žensku modu, koje je poslužilo kao neka vrsta simboličkog izjednačavanja s muškim svijetom. Na ženu u hlačama gledalo se kao na otklon od tradicionalnog društvenog strujanja i takva žena biva portretirana maskuliniziranim obilježjima. Nošenje hlača protumačeno je kao izravno upletanje u mušku sferu te je ono izazvalo živopisne rasprave u društvenim krugovima. ${ }^{31}$

\footnotetext{
28 „Što znači biti damom“, Ženski list, 5/1929., br. 5, 12.

29 „Želite li biti dobro odjevena morate poznavati svoju vanjštinu“, Naša žena, 11/1938., br. 2, 10.

30 „I haljina govori“, Ženski list, 9/1937., br. 9, 28.

31 Krešimir Kovačić, Priče iz starog Zagreba, Zagreb 1990., 222.
} 
Nadalje, zabilježen je i otpor prema stranom utjecaju na domaći odjevni kôd. Na to se gledalo kao na nešto negativno i pogubno. Može se to povezati i s potrebom određenog samoopravdavanja ili pokušaja shvaćanja nove situacije, gdje su se često novotarije razumijevale kao nešto uvozno što „kvari“ dobre domaće običaje i, u ovom slučaju, dobre domaće djevojke i žene.

\section{Zar da ženske hlače nose? \\ Tu nam modu šalje Kelt, \\ To se više trpjeti ne da, \\ Das ist die verkehrte Welt. ${ }^{\text {2 }}$}

Ni krugovi Katoličke crkve ne pozdravljaju promjene koje se javljaju u odijevanju žene.

Žalosno je, da su haljine, koje treba da pokriju tijelo, postale danas - u doba kada žene zaboravljaju svoje dostojanstvo i vrijedjaju stid - način, da se ljudi, naročito mladi, izazivaju na senzualnost. Zbog toga ne propuštamo ni jednu priliku, da skrenemo pažnju na sadašnju žensku modu, kao na izvor nesreće, i da osudimo na osnovu naše apostolske vlasti, to sramotno ponašanje žena, koje se povode nepristojnom modom. ${ }^{33}$

Modu kao nužnost prilagodbe novonastalim društvenim okolnostima nerado prihvaćaju vladajuće društvene strukture iz straha od gubitka svoje dominantne pozicije. No, $s$ druge strane, vrši se konstantan pritisak na ženu da mora pratiti modne novitete i aktivno ih slijediti.

U staromodnim bi haljinama izgledali kao stari žurnali, a po tome bili bi na smijeh i čudjenje svih ostalih, pa dapače i onih koji zapravo i nijesu odjeveni po najnovijoj modi. Stara je stvar da se na drugome mnogo bolje opažaju griješke no na samome sebi. ${ }^{34}$

\section{ZAKLJUČAK}

U radu se predstavlja odijevanje žena srednjeg i višeg društvenog sloja u Zagrebu u razdoblju međuraća. Promatra se odnos jednog od kontroverznijih društvenih fenomena kao što je moda i način na koji se promjene u njoj ostvaruju. Uzimajući u obzir širi kulturno-povijesni okvir ovog razdoblja, skiciraju se promjene u odijevanju žene i njezin položaj unutar toga izrazito turbulentnog perioda povijesti. Promjene su se događale u svim aspektima, a moda je bila samo jedan od receptora tih promjena te je zrcalila novi položaj žena u društvu i dodatno isticala njihovu samosvijest. Proučavanjem na prvome mjestu tiska (Hrvatski ženski list, Naša žena, Svijet, Ženski list) pokušava se rasvijetliti percepcija modne transformacije u Zagrebu.

Proučavani listovi namijenjeni ženskoj publici tako postaju izrazito slojeviti izvori. $\mathrm{Na}$ prvi pogled mogu djelovati kao nešto trivijalno što izvještava o raznim suvremenim kreta-

\footnotetext{
Isto.

33 „Papa protiv ženske mode“, Ženski list, 3/1927., br. 11, 0.

34 „Čavrljanje o karnevalu“, Ženski list, 1/1930., br. 1, 12.
} 
njima u svijetu mode i ljepote. No, oni vrlo brzo postaju mjesta na kojima se spajaju razni aspekti, a svaki od njih može nam protumačiti slojevitost značenja žene u međuratnom periodu. $S$ jedne strane, na njoj su, zahvaljujući velikim modnim promjenama, najvidljivije transformacije vremena. U tom vremenu i društvu žena želi sudjelovati ravnopravnije nego prije, na što je se i potiče raznim savjetima, počevši od, dakle, modnih, koji najvidljivije govore o njezinoj uključenosti. S druge strane, ženski časopisi sve češće daju i savjete i izvještaje o općenitom položaju žene ili njezinim pravima, kao i portrete raznih slavnih i uspješnih žena (posebice Ženski list). Dakle, ženu se i potiče i ohrabruje na daljnja razmišljanja o svom položaju i na daljnje korake. No, na kraju, određena je limitiranost ipak vidljiva i u primjerima različitih reakcija na "novu ženu“ te u tome da društvo ipak sporije prihvaća i razumijeva te promjene; ujedno je se ograničava, upozoravajući na ipak prihvatljivija mjerila unutar društvenog kôda.

S obzirom na to da onodobne modne tiskovine izvještavaju što bi žene trebale nositi i što se u danom trenutku nosi, kao i na sačuvani fotografski materijal, koji nam nudi prikaze odjevnih kombinacija, i dalje ostajemo uskraćeni za informacije koliko su neke modne novìne uistinu prihvatile i usvojile žene, jesu li se i stvarno nosile te kako su se žene pritom osjećale. To su pitanja koja bi se eventualno mogla istražiti na temelju zapisa (memoara) žena toga doba.

\section{$\cos$}

\section{FROM THE CORSET TO THE PANTS}

\section{FASHION IN ZAGREB BETWEEN THE TWO WORLD WARS}

Summary: In the aftermath of the First World War urban populations rose steadily, and Zagreb was no exception. In the interwar period, fashion and clothing became increasingly important to people's lives. It can be said that the period marks the beginnings of globalization and celebrity culture, which play a part in shaping emerging trends. Women, particularly those belonging to the middle and upper classes, i. e. those who can afford to keep up with the latest fashions, begin gaining more prominence in public discourse. As the most widespread and most widely-read contemporary resource on the topic, fashion magazines exert the most profound influence on the widest audience of women, shaping the female figure and social norms alike and, out of necessity, reshaping societal boundaries. Greater expectations are placed upon women as they assume a more significant role in society, which is in turn reflected in the way they dress.

Key words: Zagreb, fashion, the interwar period, woman, clothing, clothes 


\section{Izvori}

Hrvatski ženski list (Zagreb), 1940.

Naša žena (Zagreb), 1935., 1938.

Svijet (Zagreb), 1927.

Ženski list (Zagreb), 1925. - 1938.

\section{Literatura}

Ivana Biočina, Modus vivendi. Ogled o političkom, ekonomskom i društvenom u modi, Zagreb 2014.

Mirna Cvitan-Černnelić, „Odijevanje u zrcalu povijesti“, u: Moda. Povijest, sociologija i teorija mode (ur. Mirna Cvitan-Černelić, Djurdja Bartlett i Ante Tonči Vladislavić), Zagreb 2002., 11-15.

Marina Čızmić-Horvat, „Ženski listovi u hrvatskom novinstvu“, Riječ, 11/2005., br. 2, 101-107.

Karen Ellwanger, „Reformkleidung, Geschlecht und Nationalität“, u: Kleider machen Politik. Zur Repräsentation von Nationalstaat und Politik durch Kleidung in Europa vom 18. bis zum 20. Jahrhundert, Oldenburg 2002., 86-92.

Milan Galović, Moda. Zastiranje i otkrivanje, Zagreb 2001.

Josip Horvat, Povijest novinstva Hrvatske 1771-1939., Zagreb 1962.

Krešimir Kovačić, Priče iz starog Zagreba, Zagreb 1990.

Antoine LiLTi, The Invention of Celebrity, Cambridge 2017.

Ingrid Loscheк, Mode, Verführung und Notwendigkeit, München 1991.

Ingrid Loscheк, Reclams Mode- und Kostümlexikon, Stuttgart 1994.

Ingrid Loscheк, When Clothes Become Fashion: Design and Innovation Systems, Oxford - New York 2009.

Ida Ograjšen Gorenjak, Opasne iluzije. Rodni stereotipi u meduratnoj Jugoslaviji, Zagreb 2014.

Ida Ograjšek Gorenjak, „Hollywood Comes to Central Europe: The Fanamet Beauty Contest in Central Europe and Southeastern Europe“, u: The Entangled Histories of Vienna, Zagreb and Budapest (18th-20th Century) (ur. Iskra Iveljić), Zagreb 2015., 215-233.

Georg Simmel, Kontrapunkti kulture, Zagreb 2001.

Katarina Nina Simončič, Kultura odijevanja u Zagrebu na prijelazu iz 19. u 20. stoljeće, Zagreb 2012.

Aleksandar Todorović, Socijologija mode, Niš 1980.

Boris Vukonić, Tempus fugit. Povijest turizma Zagreba, Zagreb 1994.

Jutta Zander-Seidel, Kleiderwechsel. Frauen-, Männer-und Kinderkleidung des 18. bis 20. Jahrhunderts, Nürnberg 2002.

Andreja Zubac, „Kultura javne riječi ženskih časopisa od 1840. do 1970. godine“, Knjižničarstvo: glasnik Društva knjižničara Slavonije i Baranje, 20/2016., br. 2, 71-98. 
